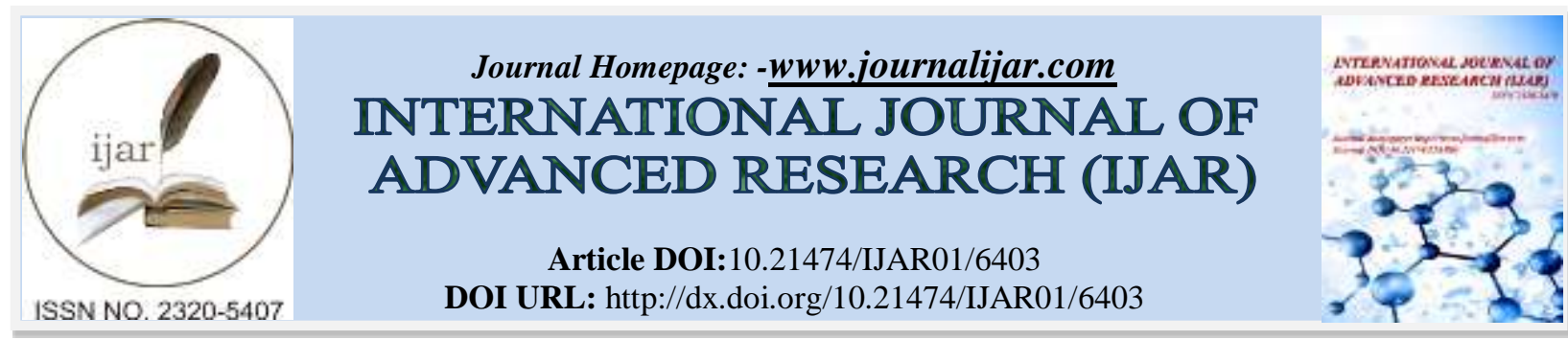

RESEARCH ARTICLE

\title{
PROTEOLYSIS AND HEAT-SENSITIVE ANTIBACTERIAL AGENTS FROM SEVERAL LEVANTINE SPONGE SPECIES.
}

\author{
Hassan A. H. Ibrahim ${ }^{1}$, Hamdy Omar Ahmed ${ }^{2}$, Fatma A. Abd El Razek ${ }^{2}$ and Elzahrae Elmasry². \\ 1. Microbiology Lab, Environment Division, ${ }^{2}$ Marine Invertebrates Lab, Aquaculture Division. \\ 2. National Institute of Oceanography and Fisheries (NIOF), Alexandria, Egypt.
}

\section{Manuscript Info}

Manuscript History

Received: 01 December 2017

Final Accepted: 03 January 2018

Published: February 2018

Keywords:-

Sponge, Levantine, Mediterranean,

Antibacterial Agent, Pathogenic

Bacteria.

\begin{abstract}
Five marine sponges were collected from six stations from the Levantine Basin in the vicinity of Alexandria city, Egypt (Spongia sp., Cinachyrella sp., Ciocalypta penicillus, Axinella verrucosa, and Plakortis simplex).The antibacterial activities against seven pathogenic bacteria; Aeromonas hydrophila, Staphylococcus aureus ATCC 6538, Pseudomonas aeruginosa ATCC 8739, Vibrio damsela, Bacillus cereus, Streptococcus faecalis and Escherichia coli, were done. The results showed that the acetone extract of Spongia $s p$. had a broad spectrum and was the most effective against $A$. hydrophila $(\mathrm{AU}=32.1)$. It was followed by ethanol extract $(\mathrm{AU}=25.5)$. Ciocalypta penicillus and $A$. verrucosa showed higher antibacterial activity against $E$. coli, where AUs were 17.4, 17.4 and 16.0 for ethanol, acetone, and methanol extracts, respectively. All extracts treated by trypsin and boiling, completely lost their bioactivities except in some cases, the bioactivities decreased to low levels. The ethanol extract of $C$. penicillus lost about $64.4 \%$ of AU against E. coli. Also, the methanol extract of $A$. verrucosa lost about $56.4 \%$ of AU against $E$. coli. The GC-MS patterns confirmed that several substances could be easily affected by proteases and temperature, such as fatty acids and their derivatives. Steroids (digoxigenin) and terpenoids ( $\beta$-Carotene betulin, astaxanthin, and rhodopsin) were also estimated to be among these extracts.
\end{abstract}

Copy Right, IJAR, 2018, All rights reserved.

\section{Introduction:-}

Sponges belong taxonomically to phylum Porifera that is classified as sessile metazoans and multi-celled immobile animals. Sponges do not possess a nervous system. Their jelly-like middle layers seem large and are composed of variable types of cells. There are cells in the outer layers that could move into the middle layer while changing their functions (Lavrov, 1995; Muller, 2003).

The fossil records showed that sea sponges have been present in the ocean for 500 million years. Nowadays, about 10.000 species have been identified by experts. The Levantine Basin is thought to be poor in sponge diversity. Only 43 species were recorded from the Levant Basin and according to Vacelet et al. (2007) this might be due to poor research.

Corresponding Author:- Hassan A.H. Ibrahim. 
Marine sponges are well investigated because of their effective metabolites, as they filter bacteria from the seawater and also possess the ability to inhibit and promote bacterial growth using their antibiotic agents. The biological activities of sponge extracts have been used, and have proven their efficiency through many modes of screening (Amade et al., 1987; Mayer and Hamann, 2009).

Moreover, marine sponges secrete high concentrations of cytotoxic chemicals to create a clear zone around their medium and prevent the growth of other species. Cytotoxicity level of potent sponges is high to the point of making a bare zone around them. Such behavior allows the sponges to grow densely on the rocks/corals as well as to compete with faster growing organisms. Although the sponges secrete these toxic substances, they can selectively use their own poisons without any self-destruction (Perdicaris et al., 2013).

Furthermore, sponges' chemical constituents and their adaptive significance originate from their myriad of chemical defenses, which are very effective against numerous species of fish and some shell-less gastropods that consider sponges as their prey (Proksch, 1994).

Considerably, marine sponges have become a significant field for discovering new bioactive compounds of either primary or secondary metabolites. However, the biological responses of novel metabolites from sponges have already been studied in many other researches (Haefner, 2000; Sipkema et al., 2005; Alcatraz and Payá, 2006; Mayer and Hamann, 2009).

The current study aims to screen crude extracts of five sponge species from the Levant Basin as a source of bioactive substances, which can be used as antibacterial agents against several human and fish pathogens. The main constitutes in the potential crude extracts were detected using GC-MS technique. Finally, the effects of trypsin, as a proteolytic enzyme, and heat on the antibacterial activity were investigated.

\section{Material and Methods:-} Sampling of sponge specimen:-

Five species of sponges (including Porifera: Demospongiae and Porifera: Homoscleromorpha) were collected using SCUBA diving of 3 to $17 \mathrm{~m}$ depth from the vicinity of Alexandria City, Egypt, from six stations in November 2013. The stations were as follows, Mostafa Kamel, Gleem, Sidi Bishr, Miami, Maamoura and Abou Qir (Figure 1). Samples were collected during the autumn season with water temperature ranging between $21-22^{\circ} \mathrm{C}$. The samples were then transferred to the invertebrate laboratory of the National Institute of Oceanography and Fisheries (NIOF) where they were sorted and cleaned from associated biota for identification and also extraction.

\section{Identification of sponge specimen:-}

All specimens used in this investigation have been carefully identified on the basis of morphological characters according to Systema Porifera (Hooper and Van Soest, 2002) and the recent update undertaken in the World Porifera Database (Van Soest et al., 2008). From each specimen, pieces of the sponge were cut and maintained immediately after collection at $-20^{\circ} \mathrm{C}$ prior to the extraction process.

\section{Preparation of different sponge crude extracts:-}

One hundred grams of each marine sponge specimen were macerated with $100 \mathrm{ml}$ of $70 \%$ aqueous ethanol, acetone, methanol and ethyl acetate. After soaking for one week, they were properly filtered through Whatman 542 filter paper. Solvents were then evaporated using rotary evaporator to obtain crude extracts (Ballantine, 1987).

\section{Bacterial reference strains:-}

The bacterial reference strains used were; Aeromonas hydrophila, Staphylococcus aureus ATCC 6538, Pseudomonas aeruginosa ATCC 8739, Vibrio damsela, Bacillus cereus, Streptococcus faecalis, and Escherichia coli. 


\section{Media and bacterial cultures:-}

Nutrient broth and nutrient agar media (Atlas, 1997); composed of (g/L): yeast extract; 2, beef extract; 1, peptone; 5 , and sodium chloride; 5 were used in all microbiological tests. Agar $(15 \mathrm{~g} / \mathrm{L})$ was added to obtain nutrient agar. All bacterial strains were maintained on nutrient agar slants. Bacterial inocula was prepared by inoculating $100 \mathrm{ml}$ of nutrient broth medium, and incubated in a shaker $(250 \mathrm{rpm})$ at $30^{\circ} \mathrm{C}$ for 24 hours until the late logarithmic phase of growth $(\mathrm{A} 550=1)$.

\section{Antibacterial bioassay:-}

The well-cut diffusion technique was applied to detect the ability of different crude extracts to inhibit the growth of the reference bacteria used. One hundred millimeters of nutrient agar medium inoculated with such bacteria were poured into plates. After solidifying, wells were punched out using $0.5 \mathrm{~cm}$ cork-porer. Fifty microliters of the tested crude extracts were transferred into each well after sterilizing by ultra-filtration using $0.22 \mu \mathrm{l}$ sterilized filters. All plates were genially incubated at the appropriate temperature for 24-48 hours.

After the incubation period, the radius of clear zone around each well (Y) and the radius of the well (X) were linearly measured in $\mathrm{mm}$, where dividing $\mathrm{Y}^{2}$ over $\mathrm{X}^{2}$ determined an absolute unit $(\mathrm{AU})$ for the clear zone. The absolute unit of crude extract, which indicated a positive result, was estimated according to the following equation (Yang et al., 1992):

$$
\mathrm{AU}=\mathrm{Y}^{2} \pi / \mathrm{X}^{2} \pi
$$

\section{Trypsin and boiling treating for selected extracts:-}

The selected crude extracts were exposed to the proteolytic enzyme represented by trypsin $\left(5 \mathrm{mg} \mathrm{ml}^{-1}\right) \mathrm{that}$ had been dissolved in $0.1 \mathrm{M}$ Tris- $\mathrm{HCl}$ buffer at $\mathrm{pH}$ 7. Each crude extract was mixed with an equal volume of the proteolytic enzyme solution and incubated at $37^{\circ} \mathrm{C}$ for 1 hour with agitation at $100 \mathrm{rpm} \mathrm{min}{ }^{-1}$. Samples of untreated crude extract with trypsin (in buffer only) served as control. After incubation time, enzyme reactions in all treatments were inactivated by boiling for 30 minutes, where the inhibitory effect of the enzyme treated-antibacterial agent was assayed (Deraz et al., 2005). These extracts were also exposed to boiling for 60 minutes; after which their antimicrobial activities were estimated (Lavermicocca et al., 1999).

\section{Chemical analysis of sponge extracts using GC-MS analysis:-}

Crude extracts produced from five different sponge species (SH1-SH5) were prepared for gas liquid chromatography-mass spectrometer (GC-MS) analysis. These extracts were concentrated until complete dryness and were finally re-suspended in the appropriate volume of the solvent. The GC-MS analysis was done with standard specifications using GC-MS model Hewlett Packard HB 5890 gas liquid chromatography coupled with 5989 B series MS. The temperature gradient program was adopted for the evaporation of the organic solvent to identify the chemical constituents. The initial temperature was $70^{\circ} \mathrm{C}$ and it gradually accelerated to $250^{\circ} \mathrm{C}$ at a rate of $10^{\circ} \mathrm{C}$ per minute. The sample was injected at $250{ }^{\circ} \mathrm{C}$ after 18 minutes. The maximum peaks representing mass to charge ratio characteristics of the antibacterial fractions, were compared to those in the mass spectrum library of the corresponding organic compounds (Thakur and Pandey, 2016).

\section{Results:-}

The Mediterranean sponges were taxonomically identified with four of them belonging to class (Porifera: Demospongiea) as follows: SH1; Spongia sp. (Linnaeus, 1759), SH2; Cinachyrella sp. (Wilson, 1925), SH3; Ciocalypta penicillus (Bowerbank, 1864), SH4; Axinella verrucosa (Esper, 1794), while the fifth species SH5; Plakortis simplex (Schulze, 1880) belonged to a different class (Porifera: Homoscleromorpha).

The antibacterial activity produced by different crude extracts of sponge species was screened against several human and fish pathogens (A. hydrophila, S. aureus ATCC 6538, P. aeruginosa ATCC 8739, V. damsela, B. cereus, S. faecalis, and E. coli).

The results showed antibacterial activity against one or more of the tested organisms. Quantitative evaluation of the antagonistic effect of these extracts was further estimated by measuring clear zones formed using the well-cut diffusion technique. 
Data shown in Table 1 and Figure 2 exhibited that the most effective extract was Spongia sp. against A. hydrophila, where its acetone extract showed $(\mathrm{AU}=32.1)$ followed by ethanol extract $(\mathrm{AU}=25.5)$. Also, $C$. penicillus showed higher antibacterial activity against A. hydrophila, where AUs were 21.8, 18.4 and 17.4 for ethanol, acetone and methanol extracts, respectively.

Following the same trend, C. penicillus and A. verrucosa showed higher antibacterial activity against $E$. coli, where their AUs were; 17.4, 17.4 and 16.0 for ethanol, acetone, and methanol extracts, respectively. Also, A. verrucosa showed higher AUs against $E$. coli, where acetone and methanol extracts recorded $\mathrm{AU}=18.8$, while ethanol extract recorded $\mathrm{AU}=16.0$.

In addition, the other extracts exhibited low and moderate activities to no antibacterial activities, especially all those against $B$. cereus. Moreover, ethyl acetate extracts for all species were found to either record the lowest AU values or no activity at all.

Results also confirmed that the acetone crude extract of all sponge species possess antibacterial activity against Gram-positive and Gram-negative bacteria, which inhibited the growth of all tested pathogens with varying degrees.

In an attempt to explore the nature of the antibacterial substance(s) produced by different sponge species, the potent crude extracts were subjected to trypsin as a proteolytic enzyme and to the boiling point. The data presented in Table 2 shows that the antibacterial activity was sensitive to both trypsin and boiling for one hour. Almost complete inhibition was achieved when crude extracts were treated with trypsin for an hour at $37^{\circ} \mathrm{C}$.

The results showed that the antibacterial substance(s) was sensitive to trypsin, suggesting that a peptide moiety is associated with its activity. The substance did not show any degree of thermal resistance, where a total loss of the activity was observed only after incubation at $100^{\circ} \mathrm{C}$ for 60 minutes.

All extracts treated by trypsin and boiling had completely lost their bioactivities, except for a few minor cases in which bioactivities were reduced to low levels. The ethanol extract of $C$. penicillus lost about $64.4 \%$ of AU; it dropped from 17.4 to 6.2 after treatments against E. coli. Also, methanol extract of A. verrucosa lost about $56.4 \%$ of $\mathrm{AU}$; it decreased from 18.8 to 8.2 after treatments against E. coli.

Furthermore, the antibacterial activity of the most effective sponge extracts was compared to some potent commercial antibiotics ( $\mathrm{mm})$. The extracts showed high inhibition zones but with higher concentrations (50 $\mathrm{mg}$ ) than those commercial antibiotics had used $(\mu \mathrm{g})$. Aeromonas hydrophila was resistant to methanol extract of A. verrucosa beside Amikacin $(30 \mu \mathrm{g})$, Cephalexin $(30 \mu \mathrm{g})$, Ciprofloxacin $(5 \mu \mathrm{g})$, and Vancomycin $(30 \mu \mathrm{g})$ antibiotics. On the other hand, E. coli showed resistance to ethanol extract of Spongia sp. and also to Amikacin $(30 \mu \mathrm{g})$, Gentamycin $(10 \mu \mathrm{g})$ and Kanamycin $(30 \mu \mathrm{g})$ antibiotics.

The GC-MS patterns of the major constituents in the powerful crude extracts ( $C$. penicillus/ethanol, Spongia sp./ethanol, A. verrucosa/ethanol, and A. verrucosa/methanol) were obtained (Figure 4).

Actually, the GC-MS patterns confirmed that several substances could be easily affected by proteases and temperature, such as fatty acids and their derivatives. Steroids and terpenoids were estimated in these extracts as well. Glycine (small amino acid) was also detected in crude extracts (Table 4 \& 5).

The largely detected fatty acids in the crude extracts were palmitic acid, oleanolic acid and octadecanoic acid, while the fatty acids derivatives were ethyl ester of pentadecanoic, hexadecanoic, tetradecanoic, otadecanoic acids and methyl ester of hexadecanoic, non-adecanoic and tetradecanoic acids.

The terpenoids were mainly determined as carotenoids such as; $\beta$-carotenebetulin, astaxanthin, and rhodopsin. The only steroid was represented by digoxigenin (Figure 5). 


\section{4-27}

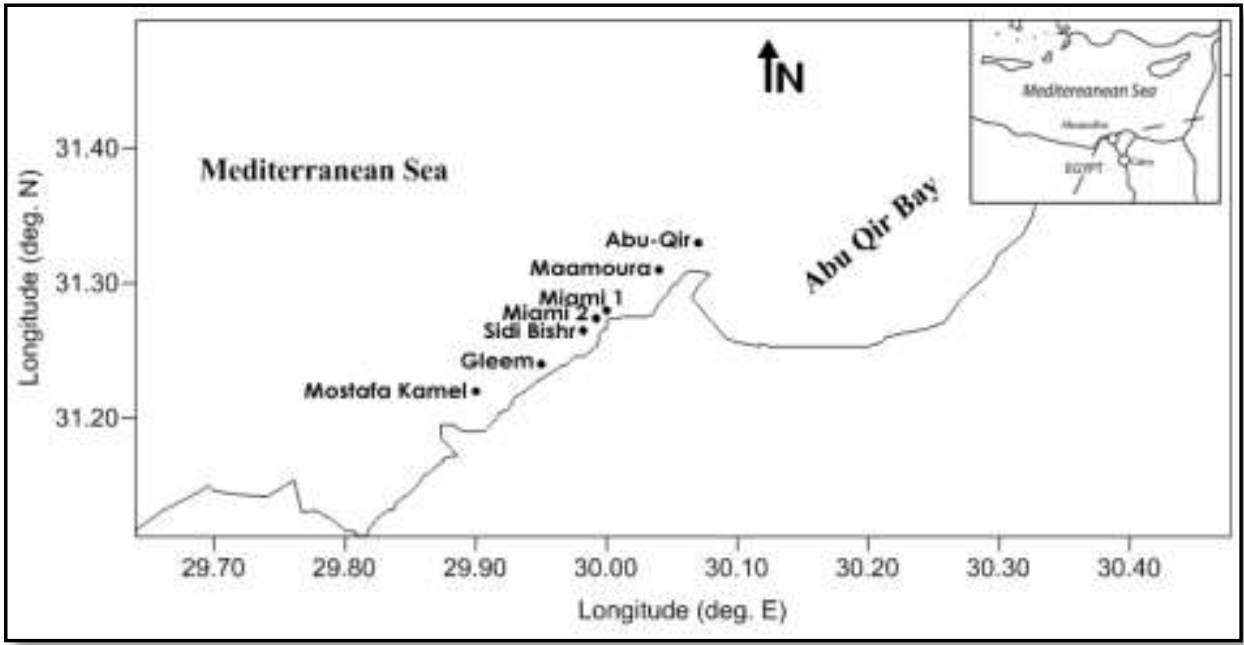

Figure 1:- Map shows sample collection locations off Alexandria City, Egypt Porifera

> Spongia

> Demospongiae

> Dictyoceratida > Spongiidae

\section{> Spongia sp.}

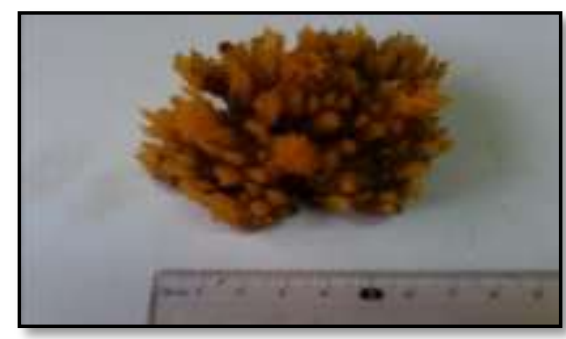

Spongia sp.

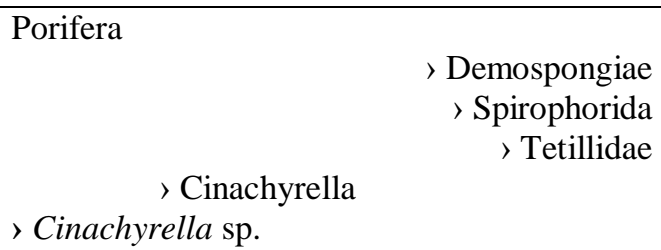

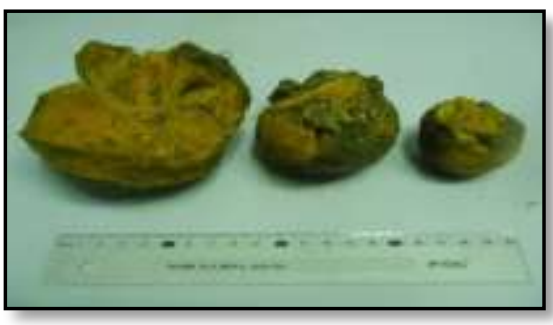

Cinachyrella sp.

\begin{tabular}{rr}
\hline Porifera & $>$ Demospongiae \\
& $>$ Halichondrida \\
& $>$ Halichondriidae \\
> Ciocalypta & \\
, Ciocalypta penicillus &
\end{tabular}

> Ciocalypta penicillus

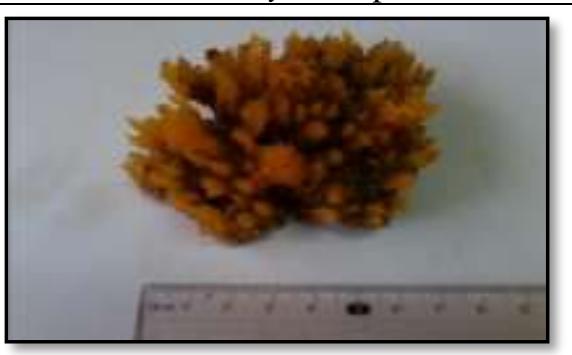

Ciocalypta penicillus 


\begin{aligned} \hline Porifera & $>\underline{\text { Demospongiae }} \\ & \frac{\text { Halichondrida }}{>\underline{\text { Axinellidae }}}\end{aligned}$

> Axinella verrucosa

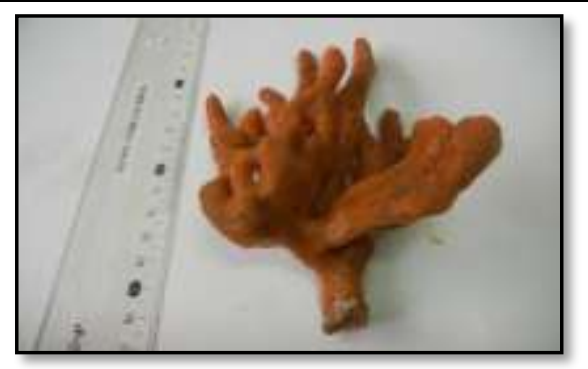

Axinella verrucosa

Porifera
$>$ Homoscleromorpha
$>$ Homosclerophorida
$>$ Plakinidae

Plakortis

> Plakortis simplex

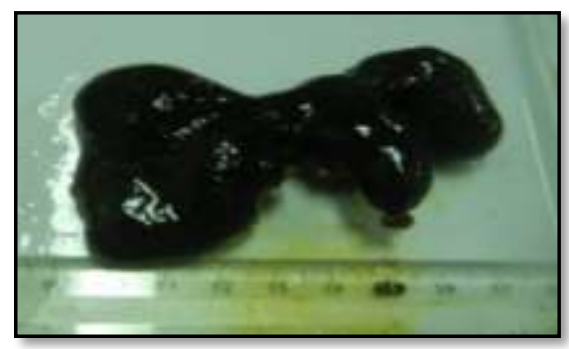

Plakortis simplex

Figure 2:- Taxonomy of sponge species under the current investigation. Notice: SH1-SH5 specimens are arranged from upper to lower

Table 1:- Screening the antibacterial activity (expressed in absolute unit; AU) of different sponge samples (50 mg) extracted by several organic solvents

\begin{tabular}{|c|c|c|c|c|c|c|c|}
\hline \multirow{2}{*}{$\begin{array}{c}\text { Sample with } \\
\text { solvent }\end{array}$} & \multicolumn{7}{|c|}{ Absolute unit (AU) } \\
\hline & A. hydrophila & S. aureus & P. aeruginosa & E. coli & $\begin{array}{c}V . \\
\text { damsela }\end{array}$ & S. feacalis & B. cereus \\
\hline \multicolumn{8}{|l|}{ C.penicillus } \\
\hline Acetone & 18.4 & 16.0 & 10.2 & 17.4 & 4.8 & 7.8 & 1.2 \\
\hline Methanol & 17.4 & 2.5 & ND & 16.0 & ND & ND & ND \\
\hline Ethanol & 21.8 & 2.8 & ND & $\mathbf{1 7 . 4}$ & ND & ND & ND \\
\hline Ethyl acetate & 8.2 & ND & ND & ND & ND & ND & ND \\
\hline \multicolumn{8}{|l|}{ Spongia sp. } \\
\hline Acetone & 32.1 & 9.0 & 2.5 & 4.8 & 1.2 & 16.0 & 1.4 \\
\hline Methanol & ND & ND & ND & ND & 8.5 & ND & ND \\
\hline Ethanol & 25.5 & 5.4 & 2.9 & 8.2 & ND & 3.5 & ND \\
\hline Ethyl acetate & ND & ND & ND & 8.2 & ND & ND & ND \\
\hline \multicolumn{8}{|l|}{ A. verrucosa } \\
\hline Acetone & 3.2 & 1.4 & 5.4 & 18.8 & 1.2 & 2.8 & 1.2 \\
\hline Methanol & 2.8 & ND & 12.8 & 18.8 & ND & 3.2 & ND \\
\hline Ethanol & ND & ND & 12.0 & 16.0 & ND & 2.5 & ND \\
\hline Ethyl acetate & 2.5 & ND & 4.0 & ND & ND & 2.5 & ND \\
\hline \multicolumn{8}{|l|}{ P. simplex } \\
\hline Acetone & 1.4 & 1.4 & 2.4 & 1.2 & 1.2 & 5.2 & 1.2 \\
\hline Methanol & ND & 2.4 & 2.4 & 2.4 & ND & 3.2 & ND \\
\hline Ethanol & ND & ND & ND & ND & ND & ND & ND \\
\hline Ethyl acetate & 2.8 & ND & ND & ND & ND & 2.5 & ND \\
\hline \multicolumn{8}{|c|}{ Cinachyrella sp. } \\
\hline Acetone & 2.5 & 1.4 & 2.5 & 2.4 & 1.2 & 3.2 & 1.4 \\
\hline Methanol & ND & 2.5 & ND & 2.5 & 2.5 & 3.5 & ND \\
\hline Ethanol & 11.1 & ND & ND & 2.5 & ND & 5.2 & ND \\
\hline
\end{tabular}




\begin{tabular}{|l|l|l|l|l|l|l|l|}
\hline Ethyl acetate & 4.0 & ND & ND & 1.8 & ND & 4.8 & ND \\
\hline
\end{tabular}

$\mathrm{ND}=$ Not detected

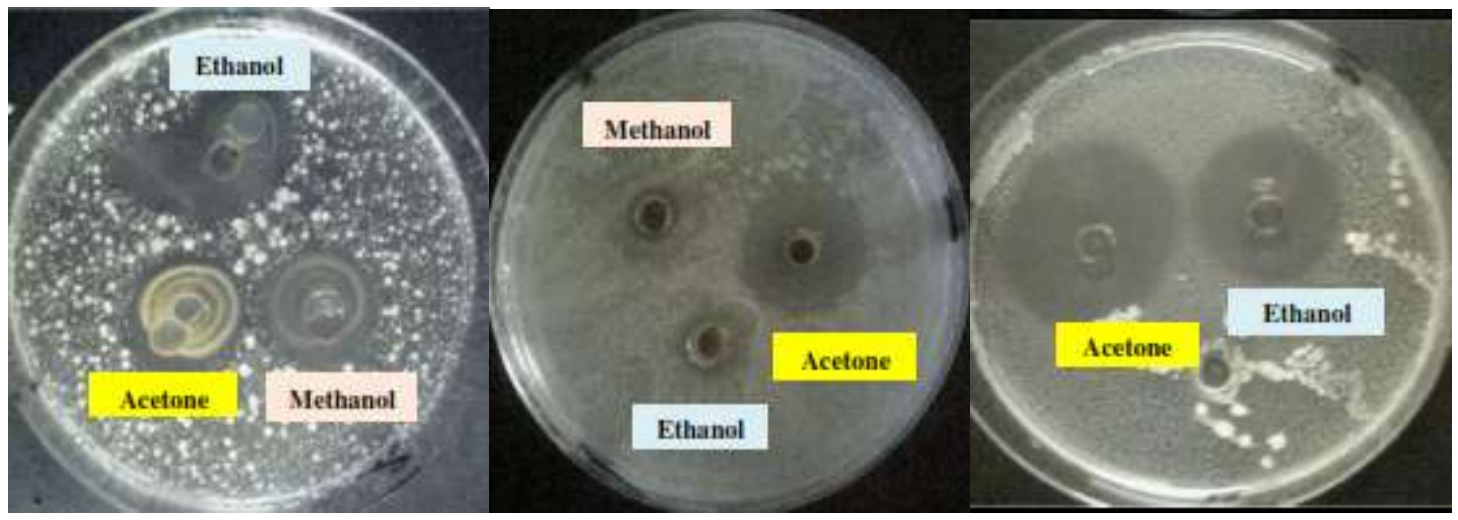

Figure 3: Macrograph showing antibacterial activity of crude extracts from C. penicillus against E. coli (left), C. penicillus (middle) against S. aureus and Spongia sp. against A. hydrophila (right) 
Table 2: Antibacterial activity (AU) of the most effective sponge samples $(50 \mathrm{mg}$ ) extracted by several organic solvents after treating with trypsin and boiling against the most affected pathogens

\begin{tabular}{|c|c|c|c|c|}
\hline \multirow[t]{3}{*}{ Sample/solvent } & \multicolumn{4}{|c|}{$\begin{array}{r}\text { AU/bacterial pathogen } \\
\end{array}$} \\
\hline & \multicolumn{2}{|c|}{ A. hydrophila } & \multicolumn{2}{|c|}{ E. coli } \\
\hline & Trypsin & Boiling & Trypsin & Boiling \\
\hline \multicolumn{5}{|l|}{ C.penicillus } \\
\hline Acetone & 4.2 & ND & ND & 6.2 \\
\hline Methanol & ND & ND & ND & 4.0 \\
\hline Ethanol & ND & ND & ND & 6.2 \\
\hline Ethyl acetate & ND & ND & ND & ND \\
\hline \multicolumn{5}{|l|}{ Spongia sp. } \\
\hline Acetone & ND & ND & ND & ND \\
\hline Methanol & ND & ND & ND & ND \\
\hline Ethanol & ND & ND & ND & ND \\
\hline Ethyl acetate & ND & ND & ND & ND \\
\hline \multicolumn{5}{|l|}{ A. verrucosa } \\
\hline Acetone & ND & ND & ND & 4.5 \\
\hline Methanol & ND & ND & ND & 8.2 \\
\hline Ethanol & ND & ND & ND & ND \\
\hline Ethyl acetate & ND & ND & ND & ND \\
\hline \multicolumn{5}{|l|}{ P. simplex } \\
\hline Acetone & ND & ND & ND & ND \\
\hline Methanol & ND & ND & ND & ND \\
\hline Ethanol & ND & ND & ND & ND \\
\hline Ethyl acetate & ND & ND & ND & ND \\
\hline \multicolumn{5}{|l|}{ Cinachyrella sp. } \\
\hline $\begin{array}{l}\text { Acetone } \\
\end{array}$ & ND & ND & ND & ND \\
\hline Methanol & ND & ND & ND & ND \\
\hline Ethanol & ND & ND & ND & ND \\
\hline Ethyl acetate & ND & ND & ND & ND \\
\hline
\end{tabular}

$\mathrm{ND}=$ Not detected

Table 3:- Comparison of the antibacterial activity $(\mathrm{mm})$ of the most effective sponge extracts to some potent commercial antibiotics

\begin{tabular}{|l|c|c|}
\hline \multirow{2}{*}{ Antibacterial agent } & \multicolumn{2}{|c|}{ Antibacterial activity (mm) } \\
\cline { 2 - 3 } & \multicolumn{1}{|c|}{ A. hydrophila } & E. coli \\
\hline Crude extract $(\mathbf{5 0} \mathbf{~ m g ) :}$ & & $25(\mathrm{~S})$ \\
\hline Acetone-C. penicillus & $25(\mathrm{~S})$ & $24(\mathrm{~S})$ \\
\hline Methanol-C. penicillus & $25(\mathrm{~S})$ & $25(\mathrm{~S})$ \\
\hline Ethanol-C. penicillus & $28(\mathrm{~S})$ & $25(\mathrm{~S})$ \\
\hline Acetone-A. verrucosa & $11(\mathrm{~S})$ & $25(\mathrm{~S})$ \\
\hline Methanol-A. verrucosa & $10(\mathrm{~S})$ & $24(\mathrm{~S})$ \\
\hline Ethanol-A. verrucosa & $0.0(\mathrm{R})$ & $13(\mathrm{~S})$ \\
\hline Acetone-Spongia $\mathrm{sp}$. & $34(\mathrm{~S})$ & $0.0(\mathrm{R})$ \\
\hline Ethanol-Spongia $\mathrm{sp}$. & $30(\mathrm{~S})$ & \\
\hline Antibiotic $($ disc/ $\mathbf{\mu g}):$ & & $0.0(\mathrm{R})$ \\
\hline Amikacin $(\mathrm{AK}, 30 \mu \mathrm{g})$ & $5(\mathrm{R})$ & $22(\mathrm{~S})$ \\
\hline Amox/Clav. $(\mathrm{AMC}, 30 \mu \mathrm{g})$ & $15(\mathrm{~S})$ & $23(\mathrm{~S})$ \\
\hline Cephalexin $(\mathrm{CL}, 30 \mu \mathrm{g})$ & $0.0(\mathrm{R})$ & $35(\mathrm{~S})$ \\
\hline Ciprofloxacin $(\mathrm{CIP}, 5 \mu \mathrm{g})$ & $0.0(\mathrm{R})$ & $0.0(\mathrm{R})$ \\
\hline Gentamycin $(\mathrm{GN}, 10 \mu \mathrm{g})$ & $22(\mathrm{~S})$ & $24(\mathrm{~S})$ \\
\hline Vancomycin $(\mathrm{VA}, 30 \mu \mathrm{g})$ & $0.0(\mathrm{R})$ & $0.0(\mathrm{R})$ \\
\hline Kanamycin $(30, \mu \mathrm{g})$ & $21(\mathrm{~S})$ & \\
\hline
\end{tabular}

$\mathrm{S}$ referees sensitivity of bacteria to the antibacterial agent used (crude extract or antibiotics), while $\mathrm{R}$ refers to resistance of bacteria to the antibacterial agent used (crude extract or antibiotics). 

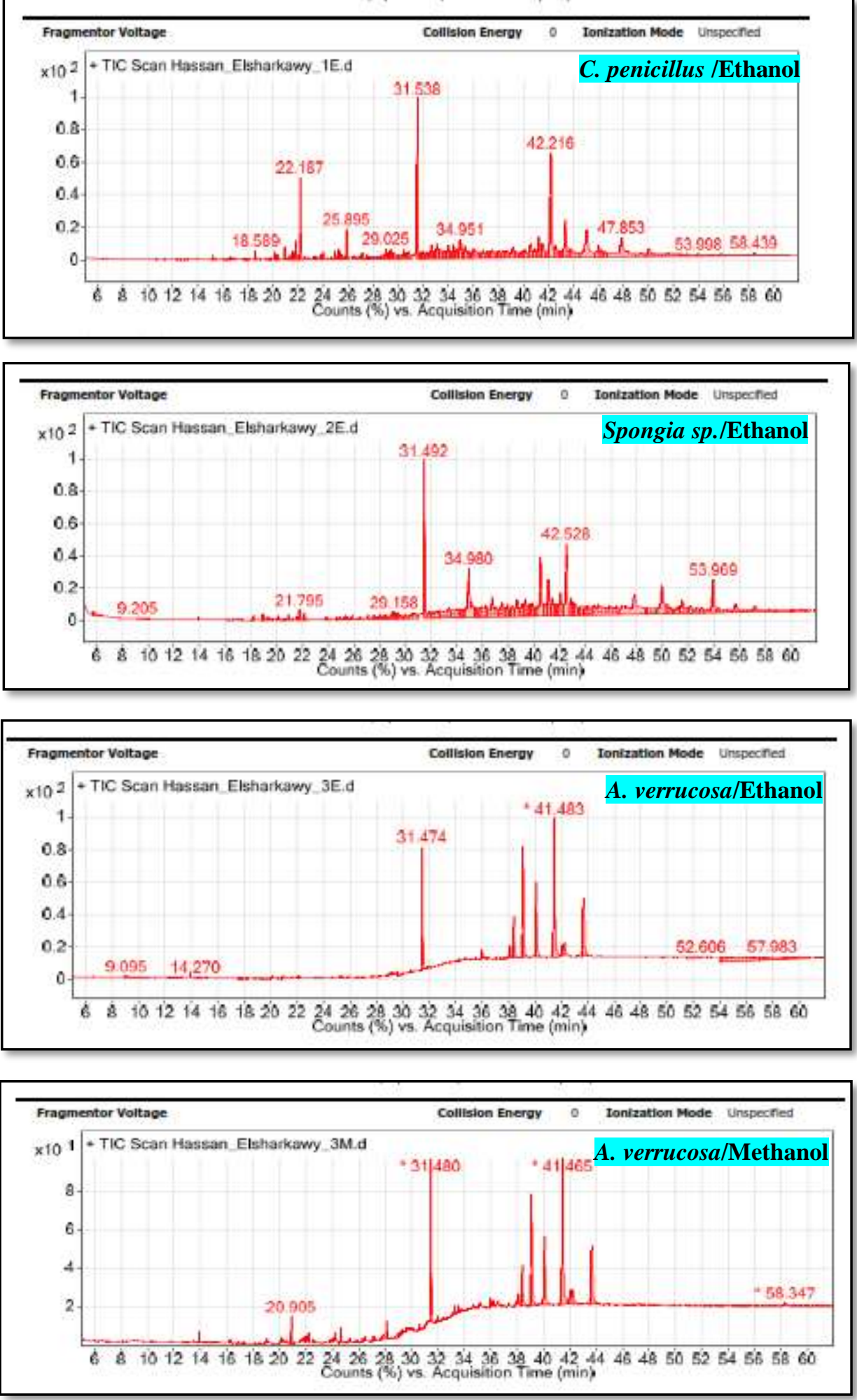

Figure 4: GC-MS patterns of major constituents in the powerful crude extracts (C. penicillus/Ethanol, Spongia sp./Ethanol, A. verrucosa/Ethanol, and A. verrucosa/Methanol) 
Table 4:- GC-MS of major fatty acids in the powerful crude extracts

\begin{tabular}{|c|c|c|}
\hline $\boldsymbol{C}$. penicillus/Ethanol & Spongia sp./Ethanol & A. verrucosa/Ethanol \& Methanol \\
\hline Pentadecanoic acid, ethyl ester & Hexadecanoic acid (Palmitic acid) & Hexadecanoic acid, methyl ester \\
\hline Hexadecanoic acid, ethyl ester & Octadecanoic acid & Octadecenoic acid, methyl ester \\
\hline Tetradecanoic acid, ethyl ester & Docosanoic acid & Oleic acid, eicosyl ester \\
\hline Octadecanoic acid, ethyl ester & Ascorbic acid & Tetradecanoic acid, methyl ester \\
\hline Oleanolic acid & & Nonadecanoic acid, methyl ester \\
\hline
\end{tabular}

Table 5:- GC-MS of major terpenoids and steroids in the powerful crude extracts

\begin{tabular}{|c|c|c|c|}
\hline \multicolumn{5}{|c|}{ Sponge species/extract-solvent } \\
\hline C.penicillus/Ethanol & Spongia sp./Ethanol & A. verrucosa/Ethanol & A. verrucosa/Methanol \\
\hline$\beta$-Carotene & $\beta$-Carotene & $\beta$-Carotene & Betulin \\
\hline Betulin & Betulin & Betulin & Astaxanthin \\
\hline Glycine & Glycine & Glycine & Digoxigenin \\
\hline Rhodopin & Rhodopin & Astaxanthin & Mirin \\
\hline
\end{tabular}

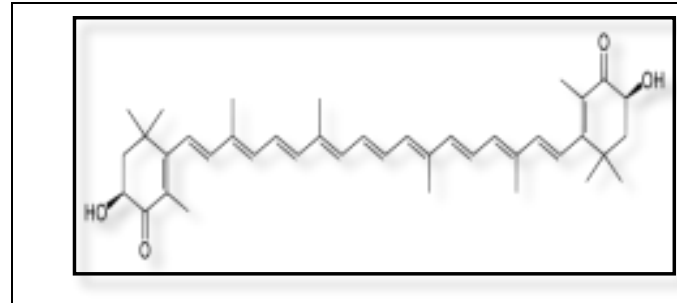

Astaxanthin

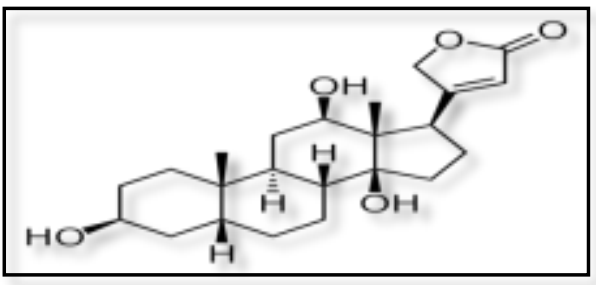

Digoxigenin

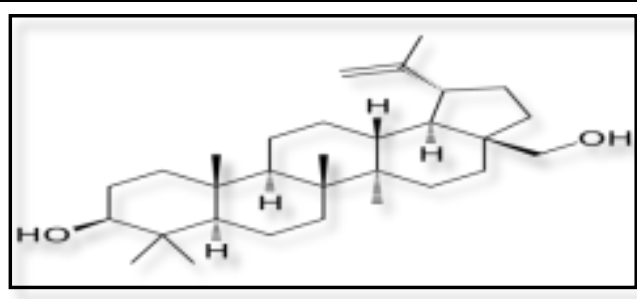

Betulin

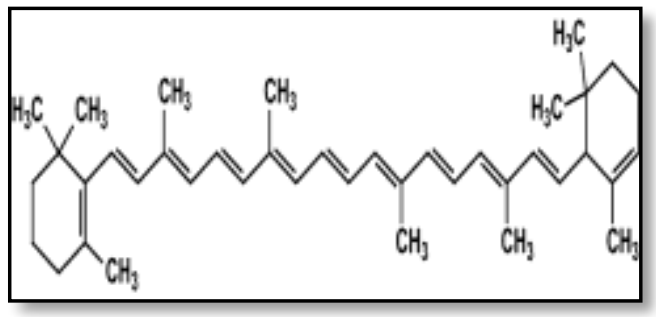

$\beta$-carotene

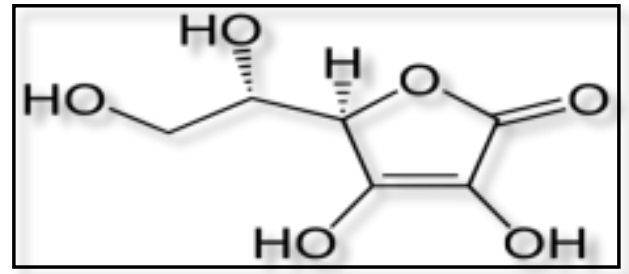

Ascorbic acid

Figure 5: Structure of main terpenoids and steroids in the powerful crude extracts

\section{Discussion:-}

Marine invertebrates are extremely diverse, widely distributed and are always exposed to huge microbial challenges from the oceanic environment which is continuously altering (Otero-González et al., 2010). On the other hand, they are considered a promising field for the discovery of novel drugs. Marine sponges have efficiently provided potent drugs against several critical diseases as cancer, malaria, microbial, viral and many inflammatory diseases (Perdicaris, 2013). 
Therefore, the current study was suggested to screen five sponge species from the Levant Basin as a source of bioactive substances, which can be used as antibacterial agents against several human and fish pathogens. The effect of trypsin as a proteolytic enzyme on their bioactivity was investigated as well.

In general, sponges have a long lifespan and are resistant to bacterial decaying. So, they are capable of providing several antibacterial agents. Indeed, the extracts of numerous sponges exhibited broad spectra of antibacterial activity. Some of these extracts were clearly active against Staphylococcus, Pseudomonas and pathogenic yeasts such as; Monila (Sharma et al., 1970).

The results obtained in the present work indicate that the activity unit by acetone extract of Spongia sp. was the most effective against $A$. hydrophila $(\mathrm{AU}=32.1)$ followed by ethanol extract $(\mathrm{AU}=25.5)$. Crude extracts of $C$. penicillus and A. verrucosa showed higher antibacterial activity against $E$. coli, where AUs were 17.4, 17.4 and 16.0 and for ethanol, acetone, and methanol extracts, respectively. Similarly, Abou-Elela et al. (2009) tested crude extracts of marine sponge against different bacterial pathogens and found that extracts of Spongia officinalis exhibited the highest inhibiting activity. Activity units ranged from 4.59 against $S$. aureus, $S$. faecalis and P. aeruginosa to 6.61 against $E$. coli. Also, it has been observed that chloroform crude extracts were more effective than those of ethanol crude. Moreover, sponge's chloroform crude extracts acted on inhibiting the growth of all pathogenic bacteria.

The experimental studies, together with previous reports, possibly categorized the nature of the antibacterial activity results from crude sponge extracts as antimicrobial peptides or substances that had been easily affected by proteases (such as trypsin) and temperature (boiling).

Mainly, trypsin is a serine protease which hydrolyses proteins by cleaving peptide chains at the carboxyl side of the amino acids arginine or lysine, unless either is followed by proline. In addition, trypsin catalyzes the hydrolysis of peptide bonds and then breaks down proteins into smaller peptides (Leiros et al., 2004).

The boiling exhibited the loss of the antibacterial activity of the crude extracts suggesting their peptide nature. The substances in the current extracts did not show any degree of thermal resistance. Similar data was obtained by AbouElela et al. (2010), since a total loss of the activity was observed for peptide nature of substances extracted from bacterial culture only after incubation at $100^{\circ} \mathrm{C}$ for 60 minutes.

Moreover, the GC-MS patterns of the present study's extracts confirmed that several substances could be easily affected by proteases and temperature, such as fatty acids and their derivatives as well as steroids such as Digoxigenin and terpenoids (mainly carotenoid) such as Astaxanthin, Betulin and Rhodopin. Additionally, glycine (small amino acid) was detected in the present study's crude extracts.

Furthermore, in the current work, the GC-MS of $C$. penicillus extracts were detected and the principal components were fatty acids and their esters (hexadecanoic acid and octadecanoic acid) which have antimicrobial effects (AbouElela et al., 2009; Ibrahim and Abd El-Naby, 2010; Ibrahim, 2012; Ibrahim et al., 2012). Fatty acids are able to act as anionic surfactants; they also possess antifungal and antibacterial characteristics at low pH (Hayes and Berkovitz, 1979). Moreover, as mentioned by Kabara et al. (1972), they are characterized by being selective against Gram positive bacteria through targeting the function and structure of cell walls and membranes.

Other workers have discussed the effectiveness of the constituents that were obtained in the crude extracts of Spongia sp. For instance, Astaxanthin is a keto-carotenoid belonging to terpenes. It is categorized as a xanthophyll but currently described as carotenoids that have oxygen-containing moities, hydroxyl or ketone, such as zeaxanthin and canthaxanthin (Mortensen and Skibsted, 1997). Cooper et al. (1975) mentioned that astaxanthin is found in microalgae, salmon, yeast, krill, trout, shrimp, crustaceans, crayfish, and the feathers of some birds. It is responsible for the red coloration of salmon meat and some cooked shellfish.

Chowdhury et al. (2002) and Green et al. (2007) reviewed that betulin and betulinic acid are naturally occurring pentacyclictriterpenoid with antimalarial, antiretroviral and anti-inflammatory characteristics. Lichfield and LiaasenJenen (1980) reported that $S$. officinalis, the common bath sponge, is a rich source of terpenoids which proved their antimicrobial and antifungal activities. 
Other substances detected in the crude extract of Spongia sp. (such as; digoxigeninis, rhodopsin, glycine, and ascorbic acid) exhibited bioactive properties by other investigators who worked on other sources rather than sponge species. For example; Polya (2003) explained that digoxigeninis, a steroid found in the leaves and flowers of the plants; Digitalis purpurea, D. orientalis and D. lanata. Britton et al. (2004) reported that rhodopin is a major carotenoid of phototropic bacteria such as Rhodomicrobium vannielii and Rhodopseudomonas acidophila strain 7050. Nelson et al. (2005) described that glycine is the smallest of the 20 amino acids commonly found in proteins, and actually is the smallest possible. Ascorbic acid which is detected in S. officinalis crude extract is a naturally occurring organic compound with antioxidant properties (Lachapelle and Drouin, 2010).

As mentioned before, the current study revealed the peptide-nature of the antibacterial efficacy of the detected $C$. penicillus crude extract. Also, Matsunaga et al. (1989) isolated an antifungal and cytotoxic cyclic tetrapeptide from a Theonella sponge and halicylindramides from the marine sponge Halichondria cylindrata. Ryu et al. (1994) concluded that the methanolic extract of marine sponge exhibited significant antifungal activity and antibacterial activity to both Gram-positive and Gram-negative bacteria. Clark et al. (1998) isolated a cyclicdipsipeptide, cyclolithistide from a marine sponge; Theonella swinhoei (Gray, 1868), and this molecule exhibited significant antifungal activity against $C$. albicans but not against $E$. coli or B. subtilis. Otero-González et al. (2010) observed that a promising novel use of antimicrobial peptides from the marine sponge Discodermia kiiensis, could be a potent drug in both human and veterinary medicine based upon their potential characteristics.

Finally, marine sponges are also considered a good source of unusual sterols, which showed potential antimicrobial activity. However, the existence of terpenoids in sponges is widespread and exhibits varied levels of bioactivities (Yasuda and Tada, 1981). Comparison of the current crude extracts of sponges to commercial antibiotics proved the efficacy of these extracts. However, they would need a strong purification process to be used in very low concentrations as commercial antibiotics.

\section{Conclusion:-}

Data obtained from this work demonstrated the sponge diversity in several locations in the Levantine off Alexandria, Egypt. The isolates obtained in this study proved evidence that marine sponges are a promising source of new bioactive molecules. Inhibitory effect of the extracts against human pathogens such; $S$. aureus ATTC 6538 and $P$. aeruginosa ATTC 8739 suggests promising applications in the clinical field. Furthermore, the inhibitory effect of the extracts against fish pathogens such as A. hydrophila suggests promising applications in the clinical field.

\section{References:-}

1. Abou-Elela, G.M., Abd-Elnaby, H., Ibrahim, H.A.H. and Okbah, M.A. (2009). Marine natural products and their potential applications as anti-infective agents. World Applied Sciences Journal, 7(7): 872-880.

2. Abou-Elela, G.M., Ibrahim, H.A.H., El-Helow, E. and Sabry, S. (2010). Abundance and antagonistic interactions among bacterioplankton in Suez Gulf. World Applied Sciences Journal, 7 (6): 748-755.

3. Alcaraz, M.J. and Payá, M. (2006). Marine sponge metabolites for the control of inflammatory diseases. Current Opinion in Investigational Drugs, 7: 974-979.

4. Amade, P., Charroin, C., Baby, C. and Vacelet, J. (1987). Antimicrobial activities of marine sponges from the Mediterranean Sea. Marine Biology, 94: 271-275.

5. Atlas, R.M. (1997). Handbook of media for environmental microbiology (p. 265, 412). Boca Raton, FL: CR Press.

6. Ballantine, D.L., Gerwick, W.H., Vetez, S.M.F., Alexander, E. and Guevara, P. (1987). Antibiotic activity of lipid-soluble extracts from Caribbean marine algae. Hydrobiologia, 151/152: 463-469.

7. Britton, G., Liaaen-Jensen, S. and Pfander, H.P. (2004). Carotenoids: Handbook. Springer. p. 109. ISBN 9783-7643-6180-8.

8. Chowdhury, A.R., Mandal, S., Mittra, B., Sharma, S., Mukhopadhyay, S. and Majumder, H.K. (2002). Betulinic acid, a potent inhibitor of eukaryotic topoisomerase I: identification of the inhibitory step, the major functional group responsible and development of more potent derivatives. Medical Science Monitor, 8(7): BR254-65.

9. Clark, D.P., Carrol, J., Naylor, S. and Crews, P. (1998). An antifungal cyclodepsipeptide, cyclolithistide A, from the sponge Theonella swinhoei. Journal Organic Chemistry, 63: 8757-8763.

10. Cooper, R.D.G., Davis, J.B., Leftwick, A.P., Price, C. and Weedon, B. (1975). Carotenoids and related compounds. XXXII. Synthesis of astaxanthin, hoenicoxanthin, hydroxyechinenone, and the corresponding diosphenols. Journal of the Chemical Society, Perkin Transactions, 1 (21): 2195-2204. 
11. Deraz, S.F., Farlsson, E.N., Hedrstrom, M., Andresson, M.M. and Mattiasson, B. (2005). Purification and characterization of acidocin D20079, a bacteriocin produced by Lactobacillus acidophilus DSM 20079. Journal of Biotechnology, 117: 343-354.

12. Green, B., Bentley, M.D., Chung, B.Y., Lynch, N.G. and Jensen, B.L. (2007). Isolation of betulin and rearrangement to allobetulin A biomimetic natural product synthesis. Journal of Chemical Education, 84: 1985.

13. Haefner, B. (2003). Drugs from the deep: marine natural products as drug candidates. Drug Discovery Today, 8: 536-544.

14. Hayes, M.L. and Berkovitz, B.K. (1979). The reduction of fissure caries in Wistar rats by a soluble salt of nonanoinic acid. Archives Oral Biology, 24: 663-666.

15. Hooper, J.N.A. and Van Soest, R.W.M. (2002). Systema Porifera: A guide to the classification of sponges. New York: Kluwer Academic/Plenum Publishers.

16. Ibrahim, H.A.H. and Abd El-Naby, F. (2010). Antimicrobial characteristics of marine polychaetes collected from Alexandria beaches. Egyptian Journal of Aquatic Research, 36 (4): 557-567.

17. Ibrahim, H.A.H., Mohamed, S.Z., El-Regal, M. and Zaki, F.A.M. (2012). Antibacterial activity of some Red Sea soft corals, Egypt. Blue Biotechnology Journal, 1(4): 497-516.

18. Ibrahim, H.A.H. (2012). Antibacterial carotenoids of three Holothuria species in Hurghada, Egypt. Egyptian Journal of Aquatic Research, 38: 185-194.

19. Kabara, J.J., Swieczkowski, D.M., Conley, A.J. and Truant, J.P. (1972). Fatty acids and derivatives as antimicrobial agents. Antimicrobial Agents and Chemotherapy, 2: 23-28.

20. Lachapelle, M.Y. and Drouin, G. (2010). Inactivation dates of the human and guinea pig vitamin C genes. Genetica, 139 (2): 199-207.

21. Lavermicocca, P., Loner, S.L., Evidente, A. and Andolfi, A. (1999). Bacteriocin production by Pseudomonas syringaepv. ciccaronei NCPPB 2355. Isolation and partial characterization of the antimicrobial compound. Journal of Applied Microbiology, 86: 257-262.

22. Lavrov, D. (1995). Porifera: Sponges. Tree of Life web project. tolweb.org/Porifera/2464

23. Leiros, H.K., Brandsdal, B.O., Andersen, O.A., Os, V., Leiros, I., Helland, R., Otlewski, J., \& Willassen, N.P., \& Smalås, A.O. (2004). Trypsin specificity as elucidated by LIE calculations, X-ray structures, and association constant measurements. Protein Science, 13 (4): 1056-70.

24. Lichfield, C. and Liaasen-Jenen, S. (1980). Comp Biochem Physiol, 66B: 359. Yasuda, F. and H. Tada, 1981. Experientia, 37: 110.

25. Matsunaga, S., Fusetani, N., Hashimoto, K. and Walchli, M. (1989). Theonellamide F: a novel antifungal bicyclic peptide from a marine sponge Theonella sp. Journal of the American Chemical Society, 111: 25822588.

26. Mayer, A.M., Rodríguez, A.D., Berlinck, R.G. and Hamann, M.T. (2009). Marine pharmacology in 2005-6: Marine compounds with anthelmintic, antibacterial, anticoagulant, antifungal, anti-inflammatory, antimalarial, antiprotozoal, antituberculosis, and antiviral activities; affecting the cardiovascular, immune and nervous systems, and other miscellaneous mechanisms of action. Biochimica et Biophysica Acta, 1790 (5): 283 -308.

27. Mortensen, A. and Skibsted, L.H. (1997). Importance of carotenoid structure in radical scavenging reactions. Journal of Agricultural and Food Chemistry, 45 (8): 2970-7.

28. Muller, W.E.G. (2003). Sponges (Porifera) Series, Progress in Molecular and Subcellular Biology/Marine Molecular Biotechnology.

29. Nelson, D.L. and Cox, M.M. (2005). Principles of Biochemistry (4 ${ }^{\text {th }}$ ed.), New York: W. H. Freeman, pp. 127: 675-77.

30. Otero-González, A.J., Magalhães, B.S., Garcia-Villarino, M., López-Abarrategui, C., Sousa, D.A. and Dias, O.L.F.S.C. (2010). Antimicrobial peptides from marine invertebrates as a new frontier for microbial infection control. The FASEB Journal, 24:1324-1334.

31. Perdicaris, S., Vlachogianni, T. and Valavanidis, A. (2013). Bioactive natural substances from marine sponges: new developments and prospects for future pharmaceuticals. Natural Products Chemistry \& Research, 1(3): 3-8.

32. Polya, G. (2003). Biochemical Targets of Plant Bioactive compounds. New York: CRC Press. ISBN 9780415308298.

33. Proksch, P. (1994). Defensive roles for secondary metabolites from marine sponges and sponge-feeding nudibranchs. Toxicon, 32: 639-655.

34. Ryu, D., Matsunaga, S. and Fusetani, N. (1994). Discodermins F-H, cytotoxic and antimicrobial tetradecapeptides from the marine sponge Discodermia kiiensis: structure revision of discodermins A-D. Tetrahedron, 50: 13409-13416. 
35. Sharma, G.M., Vig, B. and Burkholder, P.R. (1970). In: Food Drugs from the Sea (edited by H.W. Youngken), Marine Technology Society, Washington, D.C., pp: 307.

36. Sipkema, D., Franssen, M.C., Osinga, R., Tramper, J. and Wijffels, R.H. (2005). Marine sponges as pharmacy. Marine Biotechnology (NY), 7: 142-162.

37. Thakur, M.K. and Pandey, S. (2016). GC-MS analysis of pytochemical constituents in leaf extractVitex negundo [1.]. World Journal of Pharmacy and Pharmaceutical Sciences, 5(8): 672-675.

38. Vacelet, J., Bitar, G., Carteron, S., Zibrowius, H. and Perez, T. (2007). Five new sponge species (Porifera: Demospongiae) of subtropical or tropical affinities from the coast of Lebanon (eastern Mediterranean). Journal of Marine Biology Association UK, 87: 1539-1552.

39. Van Soest, R.W.M., Boury-Esnault, N., Hooper, J.N.A., Rützler, K., de Voogd, N.J., Alvarez de Glasby, B., Hajdu, E. and Cárdenas, P. (2016). World Porifera database.

40. Yang, R., Johnson, M.C. and Ray, B. (1992). Novel method to extract large amounts of bacteriocins from lactic acid bacteria. Applied and Environment Microbiology, 58 (10): 3355-3359.

41. Yasuda, F. and Tada, H. (1981). Deacetylescalaradial a cytotoxic metabolite from the sponge; Cacospongia scalaris. Experientia, 37: 110-111. 